\title{
ENG 記録のコンピュータ分析における諸問題
}

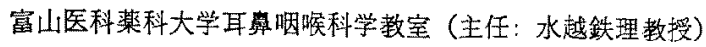 \\ 渡辺行雄, 大橋直樹, 今村純一, 水越鉄理 \\ STUDIES UPON SOME FUNDAMENTAL PROBLEMS \\ ABOUT COMPUTER ANALYSIS OF ENG EXAMINATIONS \\ YUKIO WATANABE, M. D., NAOKI OHASHI, M. D., \\ JUNICHI IMAMURA, M. D. and KANEMASA MIZUKOSHI, M. D.
}

Department of Otorhinolaryngology Toyama Medical and

Pharmaceutical University Faculty of Medicine, Toyama

Previously we reported a computer system to analyze ENG by on-line real time process.

In this paper, some fundamental conditions about computer analysis of ENG, that is, the characteristics of ENG recording system and the analyzing process of computer, and some technical problems in the use of micro-computer were studied. Amplitude and velocity of slow phase were little influenced by time constant, but fast phase velocity was influenced significantly. The experiment on effects of noise filter showed that the velocity of the fast phase was significantly lowered by a low frequency noise filter.

Sampling frequency also affected to fast phase velocity as noise filter did. It would be better to sample with high frequency, however, high sampling frequency might increase the processes work for the computer analysis.

It was generally accepted that the programing of micro-computer was simple and easy, however, in a case of complicated program as real time process of ENG, it is not simple, but rather difficult than programing of mini-computer. This might be due to the lack of detailed informations about the operating system offered by a computer maker.

Key words: ENG, コンピュータ分析, サンプリング周波数の影郘 デジタルィルタ, マイクロコンピュー夕观理

A87-1089-20092

\section{1.はしめ に}

最近，平衡機能検查のいるいろな分野にコンピュータ さかんに導入されるようになり，とくに，ENG 記録

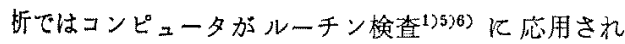
段階に至っている。私達はこれまで ENG 記録 ${ }^{374) 576)}$ コンピュータ分析についての研究を進め，実用的な JG 榆查の分析システムを開発し 報告してきたが，今

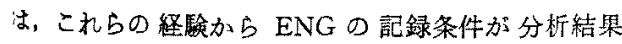
与える影響，デジタルフィルタ，サンプリング周波
数, 眼振波形とアーチファクトとの鑑別など眼運動記録 や処理上の閶題, マイコンの導入など実用段階を迎えた ENG 目動分析の諸問題について模討し 若干の考察を加 えてみた。

\section{ENG の記録杂件と雑音処理の問題}

用手㖕测的に ENG 記録を分析するとき特別な部测を 行う場合を除いて，時定数、フィルタなどの服運動䓃録 の条件が結果に影鄉することは少ない。しかし、コンピ 


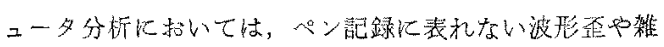

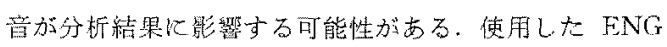

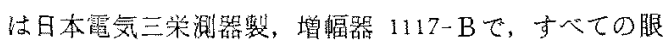
運動は12ビット变掺でサンプリングを行い，ノイズ消去 のため下位 2 ビット老切り捨てたデー夕名使用した。 ま て, 眼運動の较正は0.3 $\mathrm{Hz}$ の正弦波老用いて $1^{\circ}$ の眼浑 動がコンピュータの内部值で16となるよろにした。眼振 急速相招上び衝動性眼運動の速度は，その区䦗の原波形

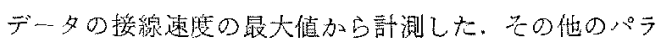
メータの計貺はさきに報告しだ〉方法上同しでする。

1) 時定数の影渂

图 1 は同一の眼振波形飞ついて, 䁃定数をD.C., 3 秒，1.5秒の3 段階での記録を比較したもので，1.5秒の記 録では纊徐相部分に歪みが生じているが，D.C.と3秒

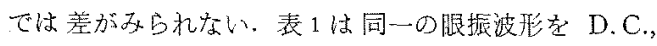

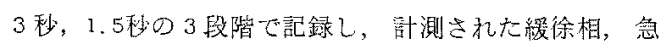
速相の振幅，速度がどのように变化ずるかみたものであ る. 高域選断つィル夕法 $25 \mathrm{~Hz}$ とした。楥徐相の振幅,

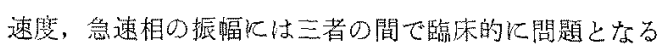
ような大きな差はみられなかった。ここで注目すべき は，急速相速度の茎である。時定数が長時間伛なるにつ れ急速相速度が低值に算出される傾向が有意の差で認め られた。通常，時定数は服運動の低速成分儿歪及与与无

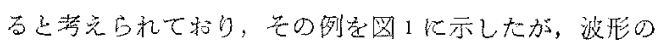
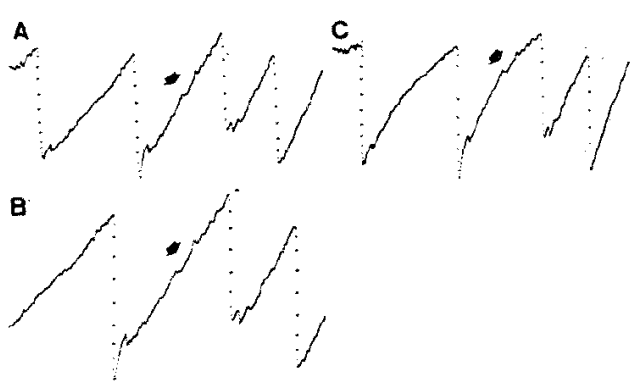

図 1 時定数が眼振波形に与光る影響 A: D.C. B: 3秒 C: 1,5秒

同じ眼振記録を 3 程類の時定数で記録した之 きの变化をみた、A，Bでは差がないが，Cで

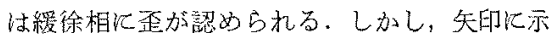
した同じ眼振口緩徐相娕度は，A，B： $22 \%$

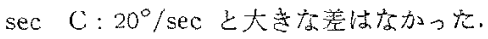

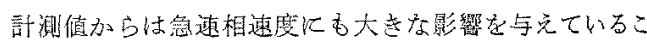

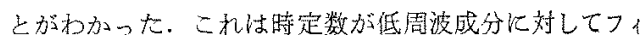
ルタとして作用したものと推察されるが真の原因封不明 で今後検討の必要がある。

2）高域遥断フィルタの影響

表 2 は振䒇 $30^{\circ}$ の衝動性眼運動速度がフィルタにより

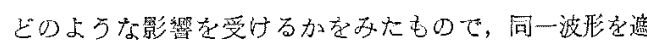
断周波数 $25 \mathrm{~Hz}, 25 \mathrm{~Hz}+$ 八厶除去八ィル夕，5Hz+八厶

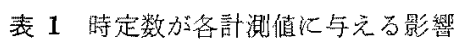

\begin{tabular}{|c|c|c|c|c|c|c|c|c|c|}
\hline \multirow{2}{*}{$\begin{array}{l}\text { 波形 } \\
\text { 番号 }\end{array}$} & \multicolumn{3}{|c|}{ 時定数：D.C. } & \multicolumn{3}{|c|}{3 秒 } & \multicolumn{3}{|c|}{1.5 利 } \\
\hline & $\mathrm{SA}$ & S V & FV & $S A$ & $S V$ & F V & S A & $S \mathrm{~V}$ & FV \\
\hline 1 & 4 & 10 & 131 & 4 & 11 & 125 & 5 & 12 & 143 \\
\hline 2 & 6 & 11 & 118 & 6 & 11 & 131 & 7 & 12 & 137 \\
\hline 3 & 3 & 11 & 87 & 3 & 13 & 93 & 4 & 14 & 100 \\
\hline 4 & 5 & 10 & 143 & 5 & 10 & 162 & 6 & 11 & 181 \\
\hline 5 & 16 & 12 & 287 & 15 & 12 & 287 & 14 & 10 & 331 \\
\hline 6 & 16 & 13 & 268 & 16 & 13 & 275 & 16 & 13 & 312 \\
\hline 7 & 2 & 18 & 256 & 2 & 18 & 256 & 2 & 15 & 293 \\
\hline 8 & 18 & 14 & 318 & 17 & 13 & 337 & 18 & 14 & 362 \\
\hline 9 & 16 & 15 & 150 & 17 & 15 & 137 & 17 & 16 & 162 \\
\hline 10 & 12 & 14 & 193 & 12 & 13 & 202 & 11 & 14 & 233 \\
\hline
\end{tabular}

$\mathrm{SA}:$ 楥徐相振幅 $\left({ }^{\circ}\right), \mathrm{SV}$ : 緩徐相速㦄 $(\% / \mathrm{sec}), \mathrm{FV}$ : 急速相速度 $(\% / \mathrm{sec})$

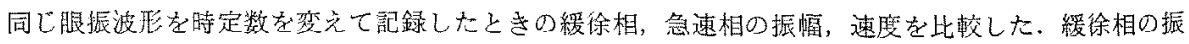

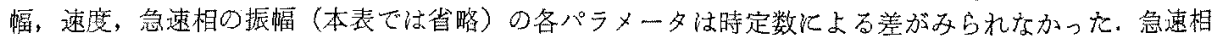

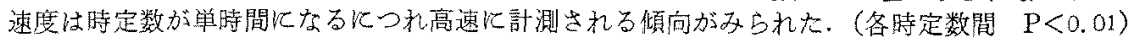


表 2 ENG の高域燠䉼つィルタが急速眼 運動速度に与觉る影響

\begin{tabular}{cc}
\hline 7 ィルタの条件 & 眼捚陲速度 $(\% / \mathrm{sec})$ \\
\hline $25 \mathrm{~Hz}$ & $509 \pm 32.9$ \\
$25 \mathrm{~Hz}+$ 八 & $451 \pm 28.2$ \\
$5 \mathrm{~Hz}+$ 八厶 & $305 \pm 17.6$ \\
\hline
\end{tabular}

振幅 $30^{\circ}$ の副動性眼運動45波形についてフィ

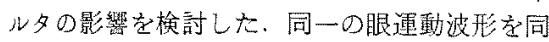
時に了種類のフィルタの条件で記錄した。 (平均值士標染偏差)

除去フィルタ波形の各条件で記銶し，計測した速度の平 均值を示した。サンプリング周波数は $100 \mathrm{~Hz}$ で別に後 述するようなデシタルフィルタを使用した，遮断周波数

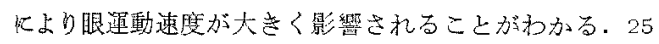
$\mathrm{Hz}$ のフィルタでは，原波形のペン記録化雑堷が增加す るが記録が大きく临害されることはない。こで、フィ ル夕の周波数特性を检討してみる。図 2 はこのENGで
$25 \mathrm{~Hz}, 25 \mathrm{~Hz}$ 十八么除去フィルタ，八ム除去フィル夕単 独の周波数特性を示したものて，八人除去フィル夕䘮湖 用すると5〜8 Hz 付近の周波数立で影響党受けること

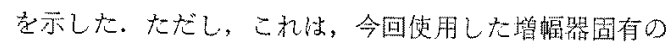
特性であり增幅舆が異なる場合には影篦の筑田が異なっ てくること榴意する必要がある。

3) デジタルフィルタについて

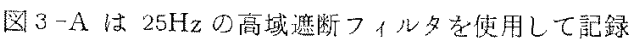

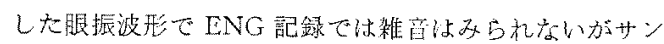
プリングしたデータでは雑音功混入しているこよがわか

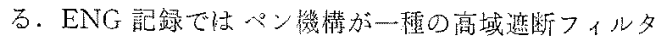
として作用するもので，サンプリングはれた多数の記䟿

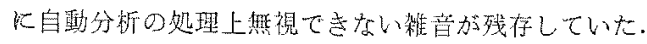
このようにENGのフィルタで除去しき扎ない倠点成分 は、データ上の1点 V $\mathrm{p}$ の俏がその前後2点ずつ計 5 点の值により， $\mathrm{V}_{\mathrm{p}}=\left(\mathrm{V}_{\mathrm{p}-2}+\mathrm{V}_{\mathrm{p}-1}+2 \mathrm{~V}_{\mathrm{p}}+\mathrm{V}_{\mathrm{p}+1}+\mathrm{V}_{\mathrm{p}+2}\right)$ 16 上なる上万に，データの各点每修正如加えこと 飞上り処舆邀程て除去している（加重移動平均法）.

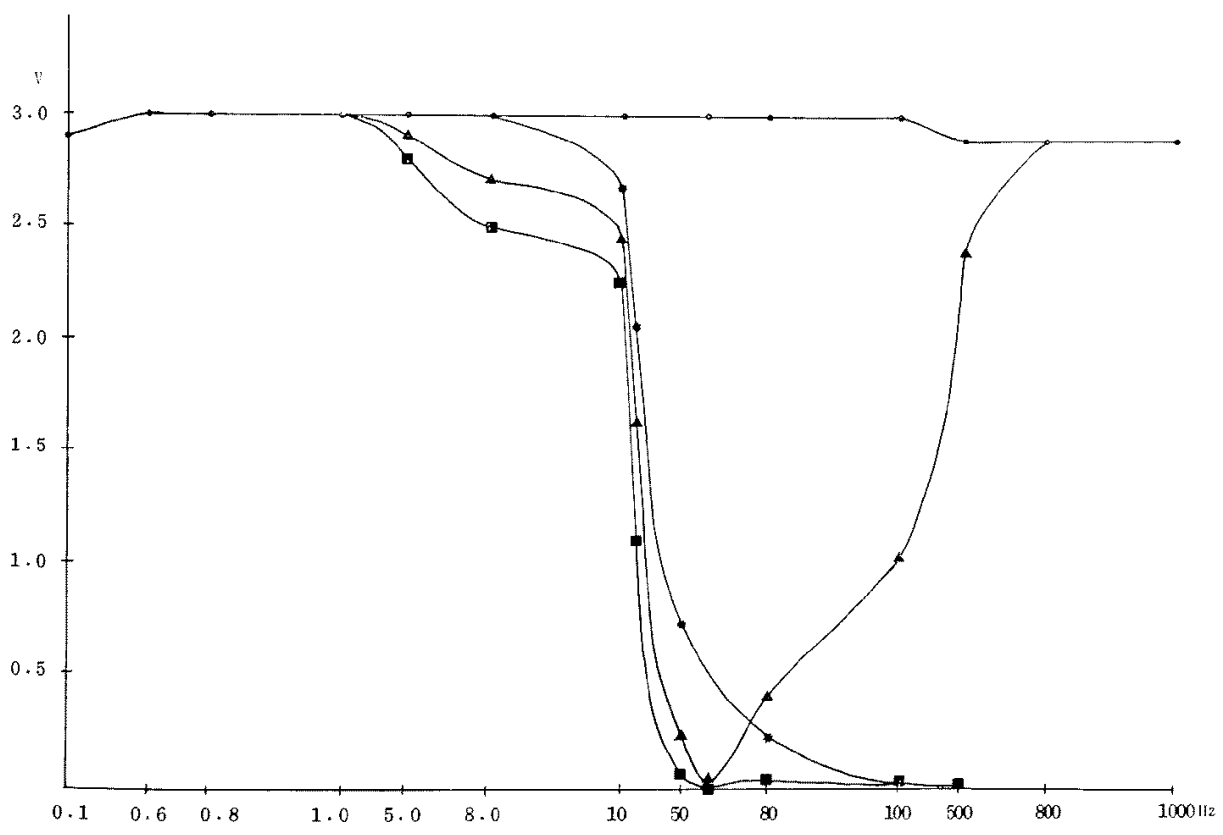

図 2 ENG の高域の高域暹断フィル夕の特性

$*$ : $25 \mathrm{~Hz}$

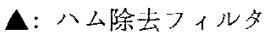

D： $25 \mathrm{~Hz}+八 ム$ 除去フィルタ

八ム除去フィルタの併用により $5 \mathrm{~Hz}$ 付近の低い周波数素で影篦が及らさよ がわかる。 


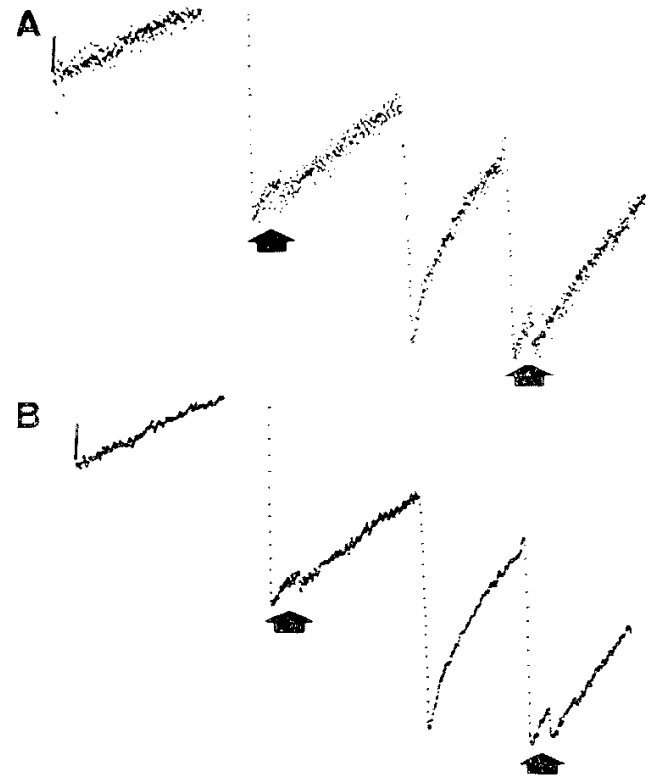

図 3 デジタルフィル夕の材果

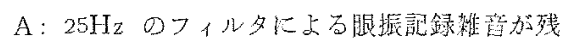
留している。

B：Aの部録夌デジタルフィルタで処理した。

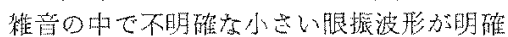
炕力ている。（经印)

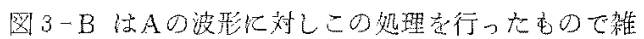

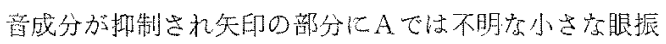
根の波形が出現していることがわかる。この上うに、デ

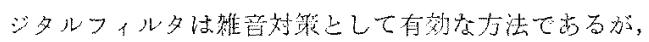

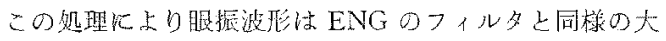

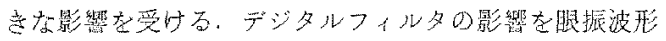

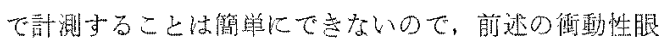
望称で一度デシタルフィルタを通過した後に再度デジタ

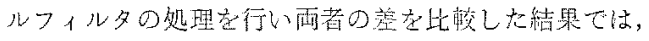

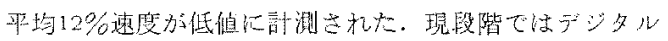

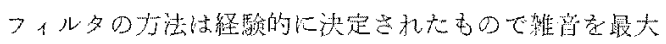

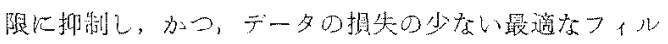

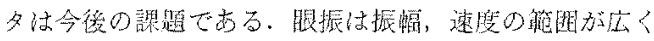

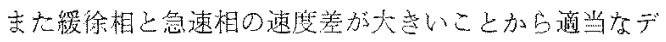

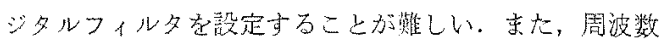

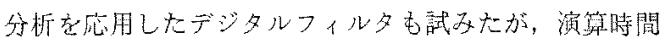
が長くなりオンライン寒時間処理に用いるフィルタとし ては問旗があっだ。

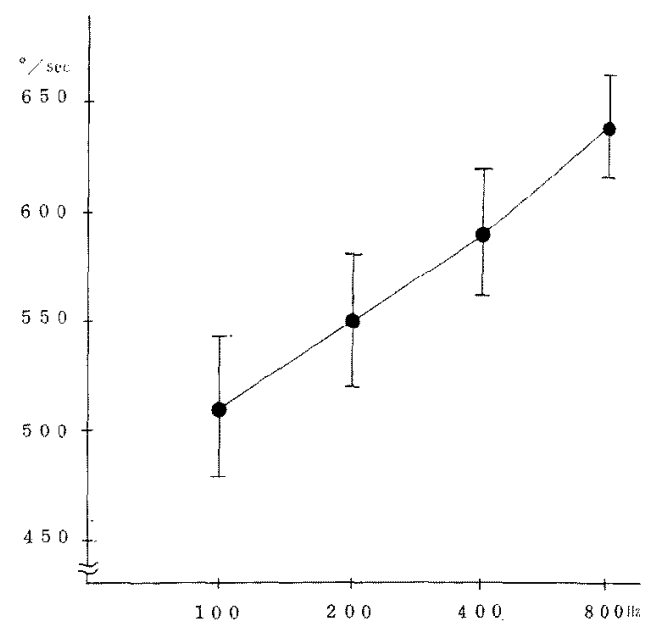

図 4 サンプリング同被数が急速眼茞動速

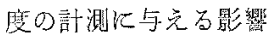

振楅 $30^{\circ}$ の衝動性眼運現速度がサンプリング 周波数によりどのように落化するかを棓測した。 同一条件で比較するため亿 $800 \mathrm{~Hz}$ でサンプり ングしたデータから $400 \mathrm{~Hz}, 200 \mathrm{~Hz}, 100 \mathrm{~Hz} 0$ データを作成した．30波形の平均值と標準涺差 孝示或。

\section{3. サンプリング周波数の影得}

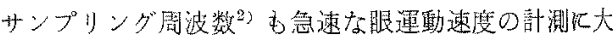

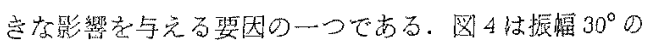
衙動性眼連動を $800 \mathrm{~Hz}, 400 \mathrm{~Hz}, 200 \mathrm{~Hz}, 100 \mathrm{~Hz}$ の畄周 波数でンプリングを行ったときの急速眼運動速度の訪

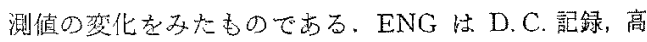
域遮断周波数 $25 \mathrm{~Hz}$ (ハム除去フィルタ使用姑す）上し て别にデジタフィル夕在処瑟段階で使用した。同一条 件で計測ができるよう飞，眼運動はます，800Hzでサン プリングを行い，このデータ加ら他の各周波数のデータ 定作成した。サンプりング周波数が低くなるにつれ速度

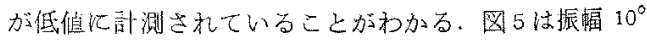

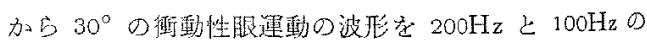
周澱数でサンプリンダしたと賞の関係をみたるのて 100 Hzで低い值学すのは当然であるが，両者の蕰線的関倸 は保たれている。秋た，サンプリング周波数が緅徐相，

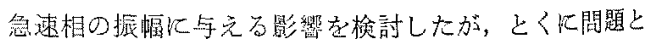
なる上万な差忧み扎な加加った。

急速眼㦈動速度の計測には高いサンプリング周波数ほ と虔好な計測がすれることになるが，とれにつれて， 


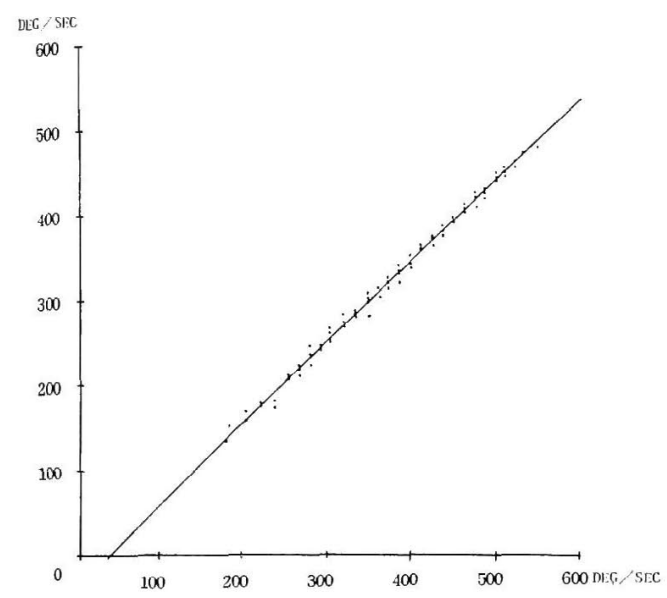

図 $5200 \mathrm{~Hz}$ と $100 \mathrm{~Hz}$ のサンプリング周 波数による急速眼運動速度の比較

横軸: $200 \mathrm{~Hz}$, 縦軸: $100 \mathrm{~Hz}$

振幅 $10^{\circ}$ から $30^{\circ}$ までの同し衝動性眼運動波形 の速度を $200 \mathrm{~Hz}$ と $100 \mathrm{~Hz}$ でサンプリングし たときの計測值を比較した. $(\mathrm{Y}=\mathrm{X}-37)$

必要な記憶容量の增加, 処理時間の延長, データの保存 コストの增加など処理側の負担が增加することも考虑に 入れるべきであるう.

\section{4. 眼振波形の鑑別とその限界}

ENG 記録には眼振の他に眼振以外の眼運動, 眼運動 以外の生体電気現象, その他の雑音など多くのア一チフ アクトが混在している。私達のコンピュータ分析システ ムでは，ENGに記録された波形の中で急速な成分を持 つ眼運動について波形認識を行い眼振波形とアーチファ クトを鑑別しており，波形分析的には眼振波形としての 鋸歯状波を適切に認識できることを報告3(4)6) してきた。 （图6）

しかし, ENG上にみられるアーチファクトのなかに は，波形的に眼振とまったく同様の形状をしたものが散 見されることがある. 図７はその例として示したあので ある.これは, ENGの電極装着直後の不安定な眼運動 の ENG 記録で，用手計測的には眼桭は発現していない がサンプリングされた波形には緅徐相と急速相を伴っ た典型的な眼振様の波形がみられる(失印). 単飞波形認 識的方法ではこれらと眼振を鑑別することは困難であ り，したがって，眼振反応を正確に自動分析するには反 応中の眼振の連続性, 方向性など新たな钼点での処理を

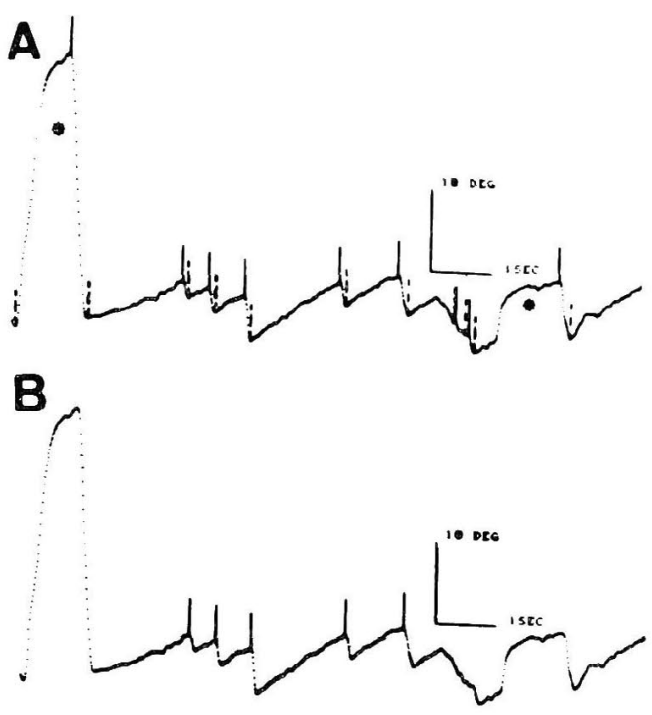

図 6 腿振とアーチファクトの鑑別

Aの*で示した波形は眼振とは言いがたいが, 眼振を表示するマーク(縦線) が付いている. Bは眼振の波形認識を行った後のもので, ア一 チファクト部分のマークが消光, 眼振波形が正 しく認識されたことを示す。

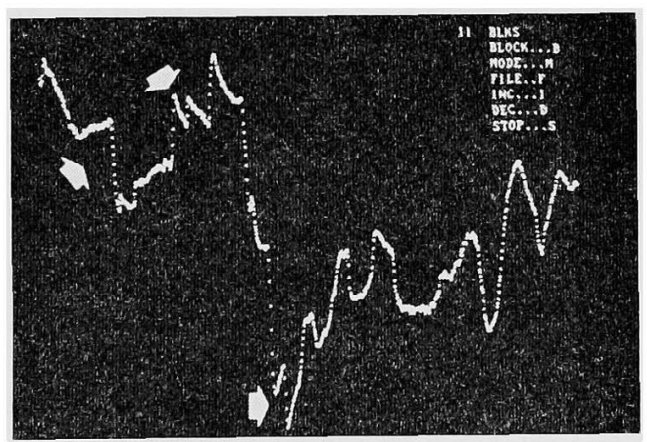

図 7 波形慧識による眼振とアーチファク 卜鑑別の限界

電極装着直後の $\mathrm{ENG}$ 波形

肉眼的にアーチファクトのみで眼振は出現し ていないが，サンプリングされた波形では眼振 様の波形がみられる.波形の連続性, 方向性を 条件に入れず波形喼識のみでこれらとアーチフ ァクトを鑑別することは困難である。

加えなければならない、このような処理はカロリックテ ストの反応開始, 終了点の認識の測定などでシステム 


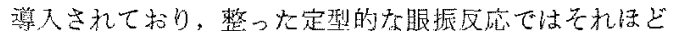
因難ではないが, 病的症例では力口りックテストやOKN の反応抑制がしばしばみられ，この上うな例では部制部 分の反灾儿種々の不定な波球がるれることが多く，こ

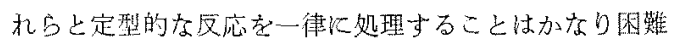

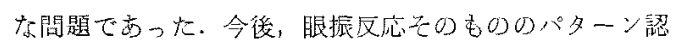
識圭檢討する必要があると考えりれた。

\section{5. 使用機器の問題（とくにマイクロコン ピュータの使用につ(てて)}

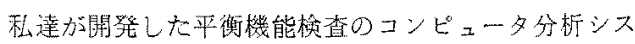
テムは，小型コンピュータによるあのてある（PDP 11/

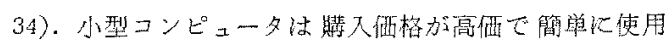
できないこど久点でらり，コンピュータ分析の普及录 故げる犬意な要因であった。最近マイクロコンピュータ の発展はめざきしく，小型コンピュータに匹敵するよう

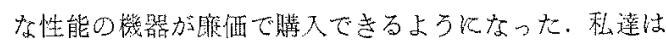
現在 PC-9801(384 K バイト，磁気ディスク：FD1120 (ICM), AD変撸器: DAS1 $298 \mathrm{PC}$ (サイエンス社), O.S.：MS-DOS）妾使用したマイクロコンピュータシ ステムにより，先に報告したオンライン実时闒処理によ

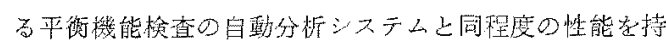

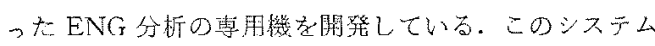
の詳細は後に報告するが，今回は，その経歌力口 ENG 分析にマイクロコンビュー多を使用する場合の閶題点に ついて述ベる.

まず，检械的な閣題见ついては，CPUは16ビットマ

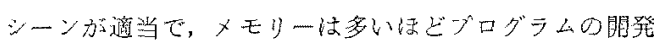
が容易になり，毁低でも128Kハト卜出必瑟である。

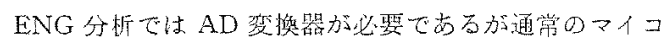

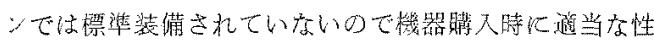

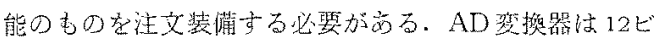

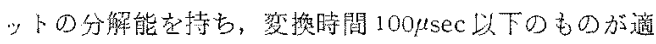

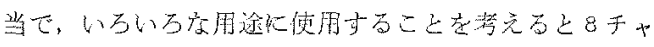

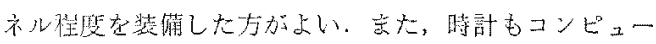

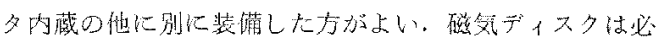

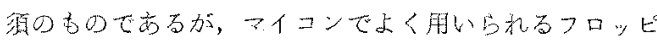

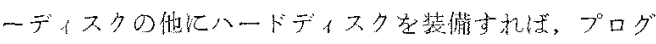

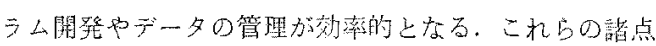
に注意す机ば, マイクロコンピュータ拉よ゙その付属装 篗の機棫的幽能は，ENG 分析用として十分であり特別 な問題姑ない。

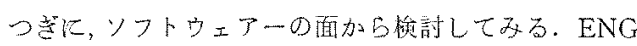

記録のオンライン実封間処理システムに和いては，1) 一定の㭙間間隔で眼運動のサンプリングを行い，データ を磁気ディスクに格納する，2）一定星のデータが蓄積 されたら眼振波形の分析を行う，3）㭘查終了之同時化 分析結果を出力する，4）キーボードまたは、ENGパネ ルのスィッチによりコンピュータシステムのコントロー ルを行万，などの処理が必要亡なる。

私涬が開発した小型コンピュータによる分析システム

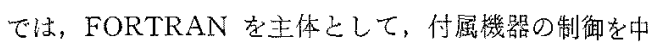
心飞かなりの部分でアセンブリー言語でのプログシム作 成吕必要であった，とくに，前記の处理のろち1，4)の 部分では，プログラム割込機能を含め付属機器の機能を 十分に活用するためにアセンブリー言語の使用心必須て あった、ーマイコンに机いても同様でありア七ンブリ一言 語によるプログラム仵成は必須の操作である。また，主 プログラムについては、現在、マイコンで BASICが

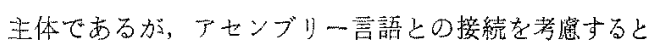
マイコンでも FORTRAN の方が有利と考光られる。

よこるで, 現段階では，マイコンのオペレーティンダ システムに招いて，アセンブリ一言語を使用する摆境が 必ずしも十分整满されてない，とくに，磁得ディスクに デ一夕を諳み整さするようなオパーティングシスデム の機能をてセンブリ一言語のレベルで利用するような場 含，また，FORTRAN からアセンブ月一言語のプログ ラムを呼び出す際の裂数の受け渡しなどは, 小型コンピ ュータでは比較的䉮易に処理できるが，マイクロコンピ

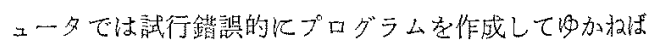

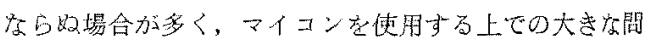
題点であった。これは、才ペレーディングシステムを提 㤨する側に十分なコンサルテーションの体制がなく，さ bに、マニュアルの記轼が不十分でユーザーに必要原情

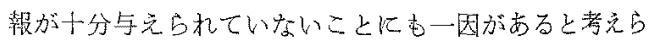
れた。

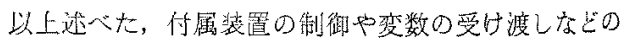
基本的な部分が解決てきき札，データの分䉼や結果の出 力などは小型コンピュータとまったく闹様炕高級言部る 体用して処理が可能でありマイクロコンピュータでしく 以䦕題となる点恬なかった。

\section{6. 考 察}

最近，平衡機能検盉のいるいるな分野に顿いてコンピ ュータの普及はめざましく，とくK， $\mathrm{ENG}^{12536)}$ の分析 でルーチン検查飞笑用的に使用される段谐洷ってい 
3. 従来, 用手計洞的に行われてきた分野にコンピュー

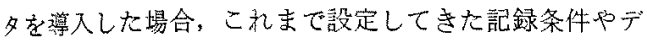

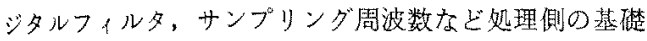
的な条件がコンピュータ分析結果にどのように影望する 加は大をな閪題である。今回，このような ENG 分析の

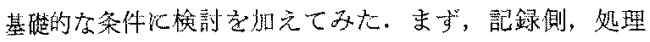

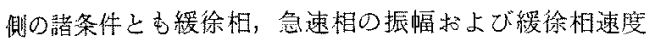
に与える影響は少なかった。したがって，眼振数，緩徐相 速度，眼振振幅に主体を和いたこれまでのパラメータの 分析については，記録，処理の諸条件を問題にする必要

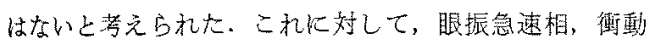
性眼運動などの念速眼軍動飞対しては，各条件とも大き な影響がタられ，とくに，アナログおよびデシタルフィ ルタ，サンプリング周波数は条件設定に上り計測值が大 きく変化することる゙示した，克た，時定数が急速眼媈動 速度の計涀に影響を与えることは私達の子想外のこと

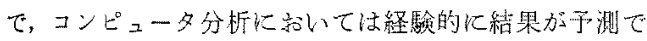
きる㛫合でも確認が必要なことを亦す絈果ですった。急

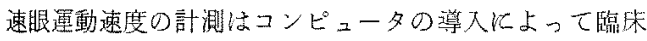
応用が期待される分姃でもあり，この上万反㮔々の条件 炕より結果が異なってくるよいうこ上を十分注賞したう

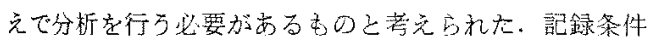
ては，記録の精度と記渌のし易さ，処理策体で纺分析精 度と処理のし易さのバンンス考䈍すべきであり，とく に，急速眼運動整度のように種々の要因が影響している 場合，特定のパラメータのみ象い水集を設定するのは得 策とは蒠光ないであるう。具体的なコンピュー夕分析 の条件設定は分析者がその目的と入手老希䖟するパラメ 一タの性質により選択することになるが，コンビュータ 分析では，雑晢の処理を例化とれば，記録段階ては，記

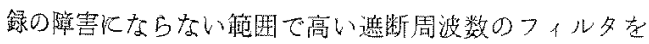
選択し㣪にデジタルィルタ安使用するなジ，できるだ け情報の損失が少ない条件で記録し，後の閜題心処理過 程で解決するの加よい上思执れた。

最近のコンピュータの普及はマイクロコンピュータに

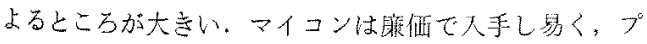

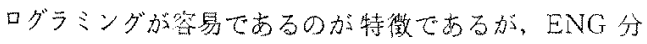
析のようなオンライン実時閶処理飞使用寸る場台にはさ きに述へた点を含めてハードウエアー，ソフトウエアー 上のいるいるな問題が生じてくる。したがって，小㤠コ ンピュータで行っているようなオンライン实封留怒玨化 よるシステム安開発するには、マイコンの詳細炕精通す る必要がある。しかし，オンライン実時䦎処理にこだす
らず，簡易な去法でデータサンプリングを奉行しバッチ 処理的にデータの分析を行方場合には，それほどプログ ラミングの因難な点はなく、データサンプリング以外の 部分は BASIC で処理が可能であり，このような方法で 留易にコンピュータ利用するの禾一法であるる。

\section{7. 綌語}

私達のこれまでの経鰠から，ENG 記録のコンピュ一 分分析を行引際の諸間題について检討し若干の考察索加

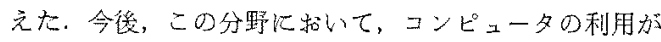
ますます盛んになることが予想されるが，よい分析を行 万には，分析の対泉となる垷㿝，分析の日的，分析火よ ってどのような程類の情報を得るかなどの点至明確にす ることが垔要と责えられた。

\section{参考文献}

1) Baloh RW, Langhofer $L$, Honrubia $V$ et al: On-line analysis of eye movement using a digital computer Aviat. Space and Environ Med 51 : 563-567, (1980).

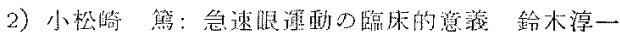

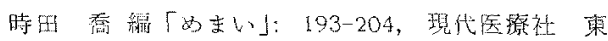
京 1983.

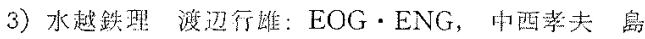

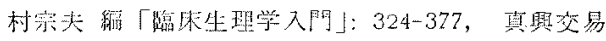
医踷 東京 1980 .

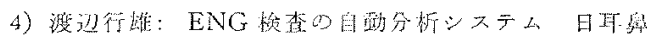
82: $1553-1578,1979$.

5) Watanabe $\mathrm{Y}$, Mizukoshi $\mathrm{K}$, Ohashi $\mathrm{N}$ et al: Computer analysis of electronystagmography re. cordings in routine equilibrium examinations. Adv ORL vol. 30, 1983.

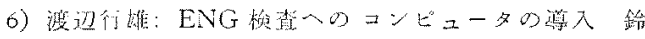

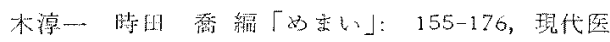
療社萫宗 1983.

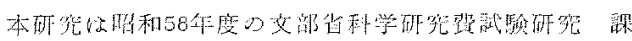

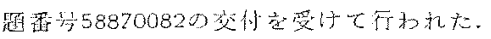

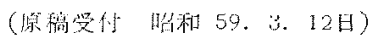

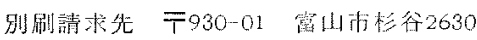

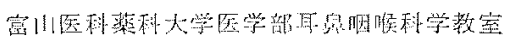
渡边行姚 